\title{
The Contribution of Tri Hita Karana Cultural Implementation and Self-Efficacy to Raise Technopreneurship In Students of Informatics Management
}

\author{
Ni Ketut Kertiasih, Universitas Pendidikan Ganesha, Singaraja, Bali, Indonesia, \\ ketut.kertiasih@undiksha.ac.id \\ Djoko Kustono, Universitas Negeri Malang, Indonesia \\ Purnomo, Universitas Negeri Malang, Indonesia \\ Eddy Sutadji, Universitas Negeri Malang, Indonesia \\ *Corresponding Author
}

\begin{abstract}
This study aimed to reveal the contribution of Tri Hita Karana cultural implementation and self-efficacy in fostering technopreneurship intentions in students of the Informatics Management Study Program. Technopreneurship is an opportunity to use as an effort to help solving unemployment problems. It can be done by entrepreneurship based on technology. The research method used was quantitative approach with the type of ex post facto research. The research samples were students of the Informatics Management Study Program with a total sample of 30 respondents. The data analysis technique used was multiple regression analysis. The results showed that the cultural implementation of the Tri Hita Karana and self-efficacy had a positive contribution to the growth of technopreneurship intentions among students of the Informatics Management Study Program.
\end{abstract}

Keywords: Cultural Implementation, Self-Efficacy, Technopreneurship, Tri Hita Karana Received: 03.12.2020 Accepted: 12.01.2021 $\quad$ Published: 06.02.2021

\section{INTRODUCTION}

Technopreneurship is one of strategies to solve unemployment problems by improving the quality of Human Resources (HR) in the mastery of science and technology (IPTEK). To become a technopreneur, it requires an innovative individual who is able to master information and communication technology (ICT) (Koe et al., 2018). Given that the current era is required to be able to master technology, then technologybased entrepreneurship should also have mastery in technology, especially in the fields of computer and internet technology. Technopreneurship is a combination of capabilities in the fields of technology and entrepreneurship by working independently to generate profits through business processes (Sumarno, Saryono, \& Gimin, 2017). Technopreneurship is an entrepreneurial process that starts with innovation (Siswadi, 2013). Technopreneurship can grow well if there is a partnership between industry, academia and government through education, training and workshop to achieve a competitive advantage (Walker, 2012).

The rapid development of ICT nowadays in the current era of globalization has had an influence in all areas of life, including also affecting the level of human needs in life (Seyyedi, 2012). The rapid development of technology has also had an impact on the development of the world of education today. The use of technology in education contributes to many pedagogical aspects where the application of information and communication technology will lead to effective learning with the help and support of the elements and components of information and communication technology (Ghavifekr \& Rosdy, 2015).

Technological advancement era will affect to many fields of work that have been filled by workers. In the future, human resource will decrease and lose in some sectors replaced by technology such as robot and artificial intelligence (AI) (Mnif, 2016). This is one of the causes of increasingly limited employment opportunities, which will have an impact on the increasing unemployment rate. Technopreneurship students have entrepreneurship opportunities for graduates. One of fields that is related to technopreneurship is Informatics Management Study Program. Students from the field are wide open, especially since students are equipped with knowledge and skills in the field of information and communication technology. According to Harlanu and Nugroho (2015) revealed that technopreneurship actors in Indonesia are still lacking so that it will open opportunities for graduates to become technopreneurs in the future. If there is an opportunity to become a technopreneurs, this opportunity should be used by Informatics Management students in an effort to help overcome 
unemployment problems by opening a business independently (entrepreneurship), namely entrepreneurship based on technology (technopreneurship).

Technopreneur is a combination of the two words namely technology and entrepreneur. Technopreneur is a business opportunity or work independently to bring profit in business processes through the ability and use of science and technology (Sumarno, Saryono, \& Gimin, 2017). A technopreneur must have creativity and be innovative in the application and use of science and technology in carrying out activities that will add value to himself and others. Increasing the readiness of student technopreneurs is important so that students can get involved in the world of work after they graduated.

Technopreneur is a technology-based business incubator, as an entrepreneurial opportunity among the younger generation. Technopreneurship is a new breakthrough strategy to deal with the increasing problem of intellectual unemployment (Muhsin, 2014). Technopreneurs can grow well if there is a partnership between industry, academia and government through education, training and coaching to achieve a competitive advantage (Ismail, Samsudi \& Widjanarko, 2017). Technopreneurship can be considered as a new breakthrough in overcoming the problem of intellectual unemployment that happens recently from a decade ago in the world (Antaranews, April 26, 2014).

Research on technopreneurship has been done a lot. Singhry (2015) states that technology-based entrepreneurial skills (including technological capabilities, relational abilities, and financial capabilities) affect technopreneurship intentions. Meanwhile, other research based on the results of their studies revealed that technopreneurship's intention was influenced by the presence of self-efficacy related to the ability to information and communication technology which included self-efficacy in the ability to master computers and the internet resource (Koe et al., 2018). Other study reviewed some of the literature and revealed factors affecting that influence technopreneurship mostly, including cultural factors, financial factors, motivational factors, and individual characteristic factors (Abdulgani \& Mantikayan, 2017). Previous study also examined the influence of the environment and entrepreneurial learning on the desire to entrepreneurship (technopreneurship) (Wati et al., 2019). There was also study stated that fostering the intention of technopreneurship can be done by using a mentoring model for each individual (Supriyati, et al., 2017). The existence of the creativity of each individual will affect the intention of technopreneurship as creativity is increasingly important to support success in entrepreneurship (Rosly et al., 2015).

The research done by Okorie revealed that the research conducted on technopreneurship that is needed and its sustainability is to pay attention to the need for underdeveloped and developing countries to realize and start promoting and adjusting technopreneurship as a way to meet the needs of life (Okorie et al., 2014). The existence of desirability and feasibility factors possessed by a person will affect creativity and intention in doing technopreneurship (Mursityo et al., 2017). Likewise, other research conducted revealed that the need for achievement, self-efficacy, instrument readiness, gender, academic achievement and work experience will also affect the intention of technology-based entrepreneurship (Santosa \& Nugroho, 2016). Technopreneurship is a program that is included in it as an integral part of enhancing entrepreneurial culture as technopreneurship needs to collaborate on culture and conceptions that include a culture of innovation, entrepreneurship, creativity, and business incubator conception (Mopangga, 2015).

However, the fact is that the technopreneurship intention of students is still low. This is due to low self-efficacy, namely the belief in the abilities of the students themselves. Self-efficacy is an internal condition that affects students' readiness to work (Utami \& Hudaniah, 2013). Self-efficacy is a belief and belief in individual abilities. Belief in this ability is related to the achievement of the desired goals (Koe, 2018). The importance of having self-efficacy is to motivate and enable students to build new businesses based on technology (Pihie \& Bagheri, 2013). Student self-confidence needs to be grown to be able to compete in the technopreneurship field. Having confidence in students' abilities will influence the choice of actions to be taken. By growing self-confidence as a strength in an effort to be entrepreneurial, looking for market opportunities and resilience when faced with obstacles or difficulties (Sahadah, 2017). Belief in one's own abilities will encourage students to understand their experiences of failure and success in the future after they graduated. This experience will enable students to express their confidence. Selfconfidence that comes from that experience will be a reference in determining his attitude.

Self-efficacy is an individual belief in their ability to produce performance that will affect their life (Bandura, 1993). Belief in individual abilities will determine how a person can think and motivate himself in behaving (Bandura, 2009). Self-efficacy is a person's belief in himself or abilities related to his actions and is one of the abilities in self-regulation of a person (Pujiyono, Minarsih, \& Haryono, 2016). Selfefficacy is the level or strength of a person's belief in his or her own ability to complete a task which can be seen as the ability to survive and a person's ability to succeed with the task (Dabas \& Pandey, 2015). 
Self-efficacy is related to individual belief in things that can be done with the existing abilities of the individual. Self-efficacy that is reflected in students is formed through the learning process that occurs through interaction with the environment. Self-efficacy is one of the aspects of self-knowledge or selfknowledge that is influential in everyday life (Ayundasari, Sudiro \& Irawanto, 2017). Confidence will be able to do something that plays a role in life related to the achievement of the expected goals (Koe et al., 2018).

Entrepreneurial behavior cannot be separated from the cultural values of society as a habit, norm, and customs which are carried out hereditary (Riana, 2011). Culture as a system that underlies values that are unique to a particular group or society, forms the development of personality traits and motivates individuals to identify aspects associated with potential entrepreneurial behavior (Mueller \& Thomas, 2001). Cultural factors can influence technopreneurship (Abdulgani \& Mantikayan, 2017). Culture also influence attitudes towards risk-taking in running their business (Anderson et al., 2015; Bygrave \& Zacharakis, 2011).

Bali has a wide variety of cultures and customs. One of the existing cultures in Bali is Tri Hita Karana (THK). THK emphasizes and teaches humans the harmony between the three human relationships in life in this world that are interrelated with each other (Riana et al., 2011; Indriyani et al., 2018). THK consists of three words, namely tri, hita and karana. Tri means three, hita maens happy, prosperous, harmonious, and karana means reason or cause (Sarwadana, 2016). Based on each word meaning, THK means three elements that cause happiness or prosperity to achieve balance and harmony, consisting of parahyangan, pawongan, and palemahan (Sarwadana, 2016; Sukarma, 2016). The three relationships are the human-human relationship (pawongan), the human relationship with the surrounding environment of society (palemahan), and the human relationship with God (parahyangan). Different cultures where humans live will have different values and beliefs that will affect their work productivity in the world (Paramita, Damayana, \& Dwiatmadja, 2014).

Balinese society has a concept of norms that governs life in its civilization since the time of the introduction of culture known as the cosmological concept of THK. This concept is a philosophy of life that has survived until now, even though it is in the concepts of social change. The concepts are always dynamic as one of the characteristics of civilization. THK is a concept in the life of the Balinese people to achieve equality and sustainable welfare (Sudira, 2011). Bali teaches its people to adhere to the THK concept, and implement it in everyday life to be able to achieve a happy and prosperous life (Sarwadana, 2016).

The Informatics Management Study Program is one of the study programs at the Diploma 3 level (D3). THK is one of the courses offered to students of the Informatics Management Study Program. It is expected that student graduates in the Informatics Management Study Program will later become technopreneurship players in Bali and in other areas, should apply THK in aspects of their life, including implementing THK in entrepreneurial activities (Riana, 2011). The THK concept emphasizes the principles of togetherness, harmony, balance and harmonization between economic goals, environmental and cultural preservation, as well as aesthetics and spirituality. In relation to entrepreneurship (business), each element in the THK culture is closely related to entrepreneurial activities. Windia and Ratna (2007) reveal that the element of parahyangan which is related to entrepreneurship is that all activities in entrepreneurship are principally controlled by God. Meanwhile, in the pawongan element, all humans as business actors are no different from other humans. Meanwhile, the palemahan element is that business actors are expected to be able to maintain harmony with the environment. So that THK, which is a concept of local cultural values that develops in the traditions of the Balinese people, is used as a foundation for business philosophy, tourism development philosophy, spatial planning, regional development strategy plans and business performance in every economic activity when humans live (Riana et al., 2011; Saputra, 2012; Putera \& Supartha, 2014).

Based on the research background, this study aimed to determine the extent to which the contribution of the cultural implementation of the THK and self-efficacy in fostering technopreneurship intentions from students of the Informatics Management Study Program.

\section{RESEARCH METHODOLOGY}

The method used in this research was quantitative approach with ex post facto as the type of research. The research method was chosen as the treatment in ex post facto research has occurred before the researcher did it and the researcher did not control the treatment. In this case the researcher only takes data to determine the contribution of the independent variable to the dependent variable to be studied. The population in this study were students of the Informatics Management Study program with a research sample of 30 respondents. 
In this study, there are three variables, namely the implementation of the culture of THK (X1), self-efficacy (X2) and intention of technopreneurship (Y). Data collection on the three variables was obtained using a questionnaire. Furthermore, the data analysis technique used is to use statistics multiple regression analysis using the help of SPSS program.

\section{RESULTS AND DISCUSSION}

The data obtained was based on a questionnaire distributed to students of the Informatics Management Study Program. Then, the calculation analysis was carried out using the help of SPSS program. The first test is to obtain the significance of the THK cultural implementation variable on technopreneurship intentions and the significance of the self-efficacy variables on technopreneurship intentions. It was carried out by using the $t$ test using SPSS. The results of the test that have been carried out are as shown in Table 1.

Table 1. The Results of $t$ Test from SPSS

Coefficients $^{a}$

\begin{tabular}{|c|c|c|c|c|c|c|}
\hline \multirow[b]{2}{*}{ Mod } & & \multicolumn{2}{|c|}{$\begin{array}{l}\text { Unstandardized } \\
\text { Coefficients }\end{array}$} & \multirow{2}{*}{$\begin{array}{c}\text { Standardized } \\
\text { Coefficients }\end{array}$} & \multirow[b]{2}{*}{$\mathrm{t}$} & \multirow[b]{2}{*}{ Sig. } \\
\hline & & $\mathrm{B}$ & Std. Error & & & \\
\hline \multirow[t]{3}{*}{1} & (Constant) & -25.146 & 25.165 & & -.999 & .327 \\
\hline & $\begin{array}{l}\text { Implementasi_Budaya_ } \\
\text { THK (X1) }\end{array}$ & .584 & .242 & .391 & 2.418 & .023 \\
\hline & Self_efficacy $(X 2)$ & .746 & .357 & .339 & 2.093 & .046 \\
\hline
\end{tabular}

a. Dependent Variable: Niat_Technopreneurship (Y)

Based on Table 1, it shows that the $\mathrm{t}$ count for THK cultural implementation variable is 0.939 with a significance of 0.023 and t count for the self-efficacy variable is 1.647 with a significance of 0.046 . The results of the significance of the two independent variables indicate the value of Sig $<0.05$. It means that the two variables namely THK cultural implementation variable and self-efficacy variable contribute to the technopreneurship intention of the Informatics Management Study Program students.

The second test was carried out to determine the contribution of the cultural implementation of the THK culture and individual self-efficacy to the technopreneurship intention of university students of the Informatics Management Study Program. The test results were carried out by using the F test using SPSS as shown in Table 2.

Table 2. The Results of F Test from SPSS

ANOVA

\begin{tabular}{|ll|r|r|r|r|r|}
\hline Model & & $\begin{array}{c}\text { Sum of } \\
\text { Squares }\end{array}$ & df & Mean Square & F & Sig. \\
\hline 1 & Regression & 184.112 & 2 & 92.056 & 6.511 & $.005^{\circ}$ \\
& Residual & 381.755 & 27 & 14.139 & & \\
& Total & 565.867 & 29 & & & \\
\hline
\end{tabular}

a. Predictors: (Constant), Self_efficacy (X2), Implementasi_Budaya_THK (X1)

b. Dependent Variable: Niat_Technopreneurship (Y)

The test results in Table 2 show that the $F$ significance value is 0.005 where $(p<0.05)$, these results indicate that the cultural implementation of the THK culture and the self-efficacy variable simultaneously contribute significantly to the technopreneurship intention of students from the Informatics Management Study Program as research samples.

Based on the results of the tests that have been carried out, it shows that the factors that contribute to fostering the intention of technopreneurship students of the Informatics Management Study Program are the implementation of the THK culture and students' self-efficacy. In fostering the intention of students to be directly involved in implementing technopreneurship activities, it is necessary to consider the balance between worldly fulfillment and religious needs in individual's being (Riana, 2011). Likewise, self-efficacy which affects a person in motivating himself and being able to survive in the face of difficulties so that the desired goals are achieved with optimal results (Bandura, 2012). 
The results of this study are supported by previous research with the same variables. The research found and stated that positive self-efficacy positively affects individual desires to be entrepreneurial (Restrepo, 2018). Santoso and Oetomo (2018) also state that self-efficacy has a significant positive effect on entrepreneurial intentions.

\section{CONCLUSION}

Based on the research results it can be concluded that: 1) there is a positive and significant contribution to the cultural implementation of the THK in fostering the technopreneurship intention of the Informatics Management Study Program Students; 2) there is a positive and significant contribution of self-efficacy in fostering the intention of technopreneurship in the Informatics Management Study Program students; and 3) there is a positive and significant contribution together with the cultural implementation of the THK culture and self-efficacy in fostering the intention of technopreneurship in the Informatics Management Study Program students. From these results, it can be stated that the more implementing the THK culture and the high self-efficacy possessed by students, the more the student's intention of technopreneurship will foster and develop well.

The intention of student's technopreneurship is a condition of the student which consists of physical, mental, skill and attitude aspects to respond to and practice a work activity. It shows that the intention of student technopreneurship is an important aspect to be prepared before students plunge into technopreneurship after graduation.

\section{REFERENCES}

Abdulgani, M.A., dan Mantikayan, J.M. (2017). Exploring Factors that Affect Technopreneurship: A Literature Review. CCSPC R\&D Journal, 1(2), 98-114.

Anderson, B.S., Kreiser, P.M., Kuratko, D.F., Hornsby, J.S., dan Eshima, Y. (2015). Reconceptualizing Entrepreneurial Orientation. Stategic Management Journal, 36, 1579-1596.

Antaranews. (2014). Teknopreneurship Solusi Atasi Pengangguran Intelektual. Diakses 15 Januari 2020, dari https://www.antaranews.com/berita/ 431256/technopreneurship-solusi-atasipengangguran-intelektual

Ayundasari, D.Y., Sudiro, A. dan Irawanto, D.W. (2017). Improving Employee Performance Through Work Motivation and Self-Efficacy Mediated By Job Satisfaction. Jurnal Aplikasi Manajemen, 15(4), 587599

Bandura, A. (1993). Perceived Self-Efficacy in Cognitive Development and Functioning. Journal Educational Psychologist, 28(2), 117-148.

Bandura, A. (2009). Cultivate Self-Efficacy for Personal and Organizational Effectiveness. In E.A, Locke (Ed)., Handbook of Principle of Organizational Behavior, (2 $2^{\text {nd }}$ Ed.), 179-200.

Bandura, A. (2012). On the Functional Properties of Perceived Self-Efficacy Revisited. Journal of Management, 38(1), 9-44.

Bygrave, W. dan Zacharakis, A. (2011). Entrepreneurship. Second Edition. USA: John Wiley \& Sons, Inc.

Dabas, D. dan Pandey, N. (2015). Rolw of Self Efficacy and Intrinsic Motivation on Work Place Environment. International Journal of Education and Psychological Research (IJEPR), 4(1), 52-57.

Ghavifekr, S., dan Rosdy, W. A. W. (2015). Teaching and Learning with Technology: Effectiveness of ICT Integration in Schools. International Journal of Research in Education and Science, 1(2), 175-191.

Harlanu, M. dan Nugroho, A. (2015). The Importance of Technopreneurship Management Model for Vocational School. Proceedings 3rd UPI International Conference on Technical and Vocational Education and Training, 147-150.

Indriyani, N.M.V., Putri, I.A.D., Suardika, IM.S., dan Wirajaya, IG. A. (2018). The Effect Good Corporate Governance and Tri Hita Karana Culture on the Quality of Financial Reporting. Russian Journal of Agricultural And Socio Economic Sciences (RJOAS), 6(78), 75-84.

Koe, W.L., Alias, N.E., Ismail, S. dan Mahphoth, M.H. (2018). A Suggested Model for Studying Technopreneurial Intention in Malaysia. International Conference on Economics, Business and Economic Education, KnE Social Sciences, 788-796.

Mnif, S. (2016). Skill Biased Technological Changes: Case of the MENA Region. Journal Theoretical and Applied Economics, XXIII(3), 339-350.

opangga, H. 2015. Studi Kasus Pengembangan Wirausaha Berbasis Teknologi (Technopreneurship) di Provinsi Gorontalo. Jurnal Trikonomika, 14(1), 13-24.

Mueller, S. L., and Thomas, A. S. (2001). Culture and Entrepreneurial Potential: A Nine Country Study of Locus Control and Innovativeness. Journal of Business Venturing, 16 (1), 51-75 
Muhsin, A. (2014). Aplikasi Technopreneurship Untuk Mengembangkan Industri Kecil Melalui Penggunaan Teknologi E-Commerce Berbasis Content Management System Studi Kasus Pada Ukm Mandiri Gypsum. Jurnal Telematika, 10(2), 91-102.

Mursityo, Y.T., Astuti, E.S., dan Suharsono, E.G. (2017). Technopreneurship Intention in Faculty of Computer Science Brawijaya University Students. Journal of Applied Management, 15(2), 320-329.

Okorie, N.N. Kwa, D.Y., Olusunle, S.O.O., Akinyanmi, A.O., dan Momoh, I.M. (2014). Technopreneurship: an Urgent Need in the Material World for Sustainability in Nigeria. European Scientific Journal, 10(30), 59-73.

Paramita, E.L., Damayana, IW., dan Dwiatmadja, C. (2014). Indigenous Entrepreneurship: The Social, Cultural and Economic Values Influence the Balinese's Entrepreneurial Development. International Conference on Business and Management - Penang, Malaysia, 1-12.

Pihie, Z.A.L. dan Bagheri, A. (2013). Self-Efficacy and Entrepreneurial Intention: The Mediation Effect of Self-Regulation. Journal Vocations and Learning, Springer, 385-401.

Pujiyono, Minarsih, M.M. dan Haryono, A.T. (2016). Pengaruh Efficacy Kemampuan Diri, Kompetensi Kerja dan Motivasi Kerja terhadap Kesempatan Kerja dengan Placement Tes sebagai Variabel Intervening. Journal of Management, 2(2). 1-30.

Putera, I D. G. W., dan Supartha, W.G. (2014). Penerapan Konsep Tri Hita Karana dalam Hubungannya dengan Budaya Organisasi di Rektorat Unud. E-Jurnal Manajemen Unud, 3(7), 1999-2014.

Restrepo, J. (2018). Self-Efficacy and Entrepreneuroal Intention: Case Study in an Intermediate City of Colombia. International Journal of Business Research (IJBR, 18(3), 67-80.

Riana, I.G. (2011). Dampak Penerapan Kultur Lokal Tri Hita Karana Terhadap Orientasi Kewirausahaan dan Orientasi Pasar. Jurnal Teknik Industri, 13(1), 37-44.

Riana, I. G., Zain, D., Troena, E.A., dan Sudarma, M. (2011). Dampak Penerapan Budaya Tri Hita Karana terhadap Orientasi Kewirausahaan dan Orientasi Pasar serta Konsekuensinya pada Kinerja Usaha (Studi pada Industri Kecil Menengah Kerajinan Perak di Bali). Jurnal Aplikasi Manajemen, 9(2), 601-610.

Rosly H.E., Junid, J., Lajin, N.F.M. and Rahim, H.L. (2015). The Relationship of Creativity and Technopreneurship Intention. International Academic Research Journal of Social Science, 1(1), 815

Sahadah, A., Rahim, M.S., John Rony Coyanda, J.R., dan Zainol, A.Z. (2017). Riding the Practice of Technopreneur Development: Key Motivating Factors to Participate and Graduate in Technopreneur's Masters Programs. International Journal of Economic Research, 14(15), 227-238.

Santosa, T.D., dan Nugroho, N.T. (2016). Faktor Yang Mempengaruhi Intensi Berwirausaha Berbasis Teknologi (Technopreneurship) Mahasiswa (Studi Kasus: Mahasiswa STMIK Duta Bangsa dan Politeknik Indonusa Surakarta). Jurnal SAINTECH Politeknik Indonusa Surakarta, 3(6), 44-51.

Santoso, S. dan Oetomo, B. S. S. (2018). Influence of Motivation and Self-Efficacy on Entrepreneurial Intention to Run a Business. Expert Journal of Marketing, 6(1), 14-21.

Saputra, K.A.K. (2012). Pengaruh Locus of Control terhadap Kinerja dan Kepuasan Kerja Internal Auditor dengan Kultur Lokal Tri Hita Karana sebagai Variabel Moderasi. Jurnal Akuntansi Multiparadigma JAMAL, 3(1), 86-100.

Sarwadana, S.M. (2016). Aplikasi Tri Hita Karana untuk Meningkatkan Kualitas Diri. Denpasar: CV. Kayumas Agung.

Seyyedi, F. (2012). Sociological Impact of Information Technology on Social Networks. International Journal of Information and Education Technologi, 2(2), 108-110.

Singhry, H. B. (2015). The Effect of Technology Entrepreneurial Capabilities on Technopreneurial Intention of Nascent Graduates. European Journal of Business and Management, 7(34), 8-20.

Sudira, P. (2011). Praksis Ideologi Tri Hita Karana dalam Pembudayaan Kompetensi Pada SMK di Bali. Disertasi. Program Studi Pendidikan Teknik Kejuruan, Program Pascasarjana, UNY

Sukarma, IW. (2016). Tri Hita Karana Theoritacal Basic of Moral Hindu. International Journal of Linguistics, Language and Culture (IJLLC), 2(9), 84-96.

Sumarno, Saryono, dan Gimin. (2017). Pengembangan Technoprenurship di Universitas Riau. Jurnal Promosi, Jurnal Pendidikan Ekonomi UM Metro, 5(2), 85-94.

Supriyati, E., Iqbal, M., dan Khotimah, T. (2017). Mentoring Model for Technopreneurship Through Neurocoaching to Grow up Technopreneurship Intention of Students at Muria Kudus University. International Journal Technology and Business, 1(2), 70-75.

Utami, Y.G.D. dan Hudaniah. (2013). Self Efficacy dengan Kesiapan Kerja Siswa Sekolah Menengah Kejuruan. Jurnal Ilmiah Psikologi Terapan, 01(01), 40-52.

Walker, K. (2012). The Technopreneurship Process: Academin Entrepreneur University Spin-Offs. Journal RIThink, 2, 11-22. 
Wati, F.F., Sukmawati, L., dan Alamsyah, D. (2019). Pengaruh Lingkungan Kampus dan Pembelajaran Terhadap Keinginan Berwirausaha (Technopreneur) pada Mahasiswa. Journal of Technopreneurship and Information System (JTIS), 2(2), 42-47.

Windia, W. dan Ratna, K. D. (2007). Analisis Bisnis yang Berlandaskan Tri Hita Karana. Denpasar: Penerbit Universitas Udayana. 